\title{
ジオシンセティックスの道路舗装分野への利用 軟弱路床・路盤分離への適用一室内試験方法の検討
}

\author{
ジオシンペイブ研究会（東洋紡績株式会社） ○石川雅洋同左 足立将孝
}

近年、軟弱な路床に対する路床構築方法として、路床改良や置換工法をとらず、ジオシンセティックスを 軟弱路床・路盤分離シートとして直接路床上に敷設する工法が検討されている。本工法において、道路建 設初期にジオシンセティックスが受ける破壊力は大きく、損傷を受ける可能性がある。そのため、施工時 の形態および物性保持性であるサバイバビリティーの評価が重要である。しかし、本工法でジオシンセテ イックスが受けるような損傷を評価する共通的な試験法は存在しない。当研究会では、実際の施工現場と 整合性のある評価試験法の開発を目指し、ローラーコンパクタ試験法と I S O 淮拠試験法の二つの試験法 を検討している。その結果、不織布は織布に比べて損稘を受けにくいことが判った。また、路盤材の沈下 量の增加と共に引張強さ保持率が低下し、損傷が大きくなることが判った。両試験法の比較においては、 ジオシンセティックスの損傷の受け方に違いがあることが判った。 キーワード : ジオシンセティックス、道路、分離、室内試験方法、サバイバビリティー

Application of Geosynthetics for Pavement Construction: Geosynthetics for Separation Between Soft Subgrade and Base Course - An Evaluation of Smal1 Scale Model Testing Methods

M. Ishikawa and M. adachi:a society for the study of Geosyn-pave (TOYOBO CO., LTD)

Recently, compared with Subgrade Reform Method and Soil Replacement Method for road construction, application of geosynthetics for the separation material between soft subgrade and base course seems to be preferable. In the early stage of pavement construction, destructive forces caused by heavy constructive machine work on geosynthetics are very large and the damage of geosynthetics would be considerably. Therefore, survaivability of strength of geosynthetics must be evaluated. A standard testing method to evaluate the damage of geosynthetics during construction has not established yet.Geosyn-pave society investigated two testing methods using conventional roller compactor or repetitive fatigue testing machine proposed by ISO. As the result, it was found that nonwoven fabrics are damaged less than woven fabrics. As the subsidence of base course material increases, the damage of geosynthetics becomes severely. In these testing methods, geosynthetics are affected by different destructive forces.

Keywords:Geosynthetics, Pavement, separation, Small Scale Model Testing Method, Survivability 


\title{
ジオシンセティックスの道路舗装分野への利用 軟弱路床・路盤分離への適用一室内試験方法の検討
}

\author{
ジオシンペイブ研究会（東洋紡績株式会社） ○石川雅洋＼cjkstart同左 足立将孝
}

\section{1.はじめに}

近年、道路舗装分野において工事費削减や工期短縮、公害防止、省エネなどの理由から、軟弱な路床に 対する路床構築方法として、セメント・石灰等による路床改良や良質土による㯰換え工法をとらず、ジオ シンセティックスを軟弱路床・路盤分離シートとして路床上に直接敷設する工法が検討されている。

しかし、本工法において、特に道路建設初期に路盤材の撒き出しや建設機械の走行によってジオシンセ ティックスが受ける破壊力は意外に大きく、道路供用後にジオシンセティックスが定常的に受けるカより もはるかに上回るものである。そのため、施工時の形態・物性保持性であるサバイバビリティー評価が重 要である。

\section{2. 試験目的}

現在、ジオシンセティックスに適用される一般的な損稘、破壊試験としては、貫入試験、コーン落下試 験、破裂試験などが挙げられる。しかし、軟弱路床・路盤分離シートとしてのジオシンセティックスの損 傷などを評価する共通的な試験法は存在しない。このような状況に対して、財団法人土木研究センター内 に設置されたジオシンペイブ研究会では、塞際の施工現場と整合性のあるサバイバビリティー評価試臨法 の確立を目指し、ローラーコンパクタ試験法とＩＳＯ準拠試験法（絽返し载荷試験）の二つの試験法に絞 り込んで調查研究を行い、どちらの試験法が標準化に適しているかの検討を行っている。

本報告では、標準材料を使用した場合の両試験法での検討およびその比較検討について述べる。

ここで、ローラーコンパクタ試験法とは、実際の施工現場におけるアスファルト混合物の締固めを模し た機械であるローラーコンパクタを用いた試験法である。また、I S O 準拠試験法とは、1997 年 7 月 に I S Oで提案されたジオシンセティックスの損傷試験に準拠した方法であり、これは骨材間に敷設した ジオシンセティックスに繰返し圧縮荷重を加えるものぶれて

3. 試験方法

(1) ローラーコンパクタ試験法の概略を図 1 に示す 本試験法は寸法 $30 \mathrm{~cm} \times 30 \mathrm{~cm} \times 5 \mathrm{~cm}$ あるいは 50 $\mathrm{cm}$ (転圧方向） $\times 30 \mathrm{~cm} \times 5 \mathrm{~cm}$ の型枠を二段積み重 ね、その間にジオシンセティックスを敷設（周辺部 固定あるいは未固定）し、载荷ローラーで転圧する ことによってジオシンセティックスに損傷を与える

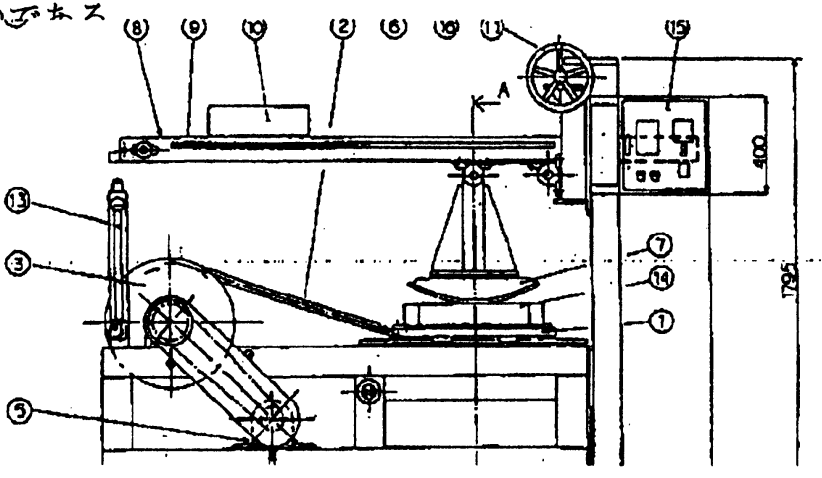

図 1 ローラーコンパクタ試験 
ものである。

（2）I SO準拠試験法の概略を図 2 に示す。本試験法 は寸法 $30 \mathrm{~cm} \times 30 \mathrm{~cm} \times 7.5 \mathrm{~cm}$ の下部型枠と $30 \mathrm{~cm}$ $\times 30 \mathrm{~cm} \times 10 \mathrm{~cm}$ の上部型枠（路盤材厚 : $3 \mathrm{~cm}$ ）の間 にジオシンセティックスを敷設（一端固定）し、寸法 $20 \mathrm{~cm} \times 10 \mathrm{~cm}$ の載荷平板を用いて載荷圧力 $5 \sim 9$ $00 \mathrm{kPa}$ (約 $0.05 \sim 9.2 \mathrm{kgf} / \mathrm{cm}^{2}$ ) の正弦波、振動 数 $1 \mathrm{~Hz}$ で繰返し荷重を 200 回加えることによって ジオシンセティックスに損傷を与えるものである。

(3) 平成 10 年度調査研究では、試験素材として両試 験法とも路床材には $8 \mathrm{~mm}$ 以下の細粒分を除去した硬質 人工 6 号砕石人工 6 号砕石（セラサンド，シノパール；

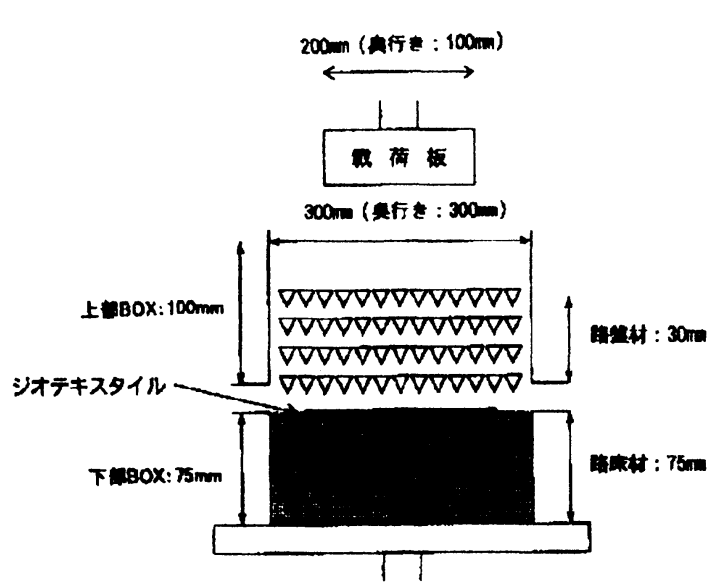

図 2 I S O 準拠試験法

美州興産(株) 製) とウレタンゴム板（硬度 $30 ， 45 ， 60$ ）を使用した。路盤材には路床材と同様の 8 $\mathrm{mm}$ 以下の細粒分を除去した硬質人工 6 号砕石を使用した。下記の表 1 に使用した硬質人工 6 号砕石の物 性を示す。

(4) ジオシンセティックスには 3 種類のポリエステルスパンボンド不織布（ポリエステル長繊維不織布） のニードルパンチタイプ（以下、S B と略す。）とポリエステル織布を使用した。下記の表 2 に使用した ジオシンセティックスの物性を示す。

(5) 本試験におけるサバイバビリティー評価として、形態保持性については外観目視観察による評価を行 い、物性保持性については損賃試験前後の引張強さ保持率による評価を行った。引張試験は J I S L

1908 に準拠して測定を行った。

表 1 硬誓人工 6 号砕石の物性

\begin{tabular}{|c|c|c|c|c|c|}
\hline $\begin{array}{l}\text { 硬簧人工 } \\
6 \text { 号砕石 }\end{array}$ & $\begin{array}{c}\text { 粒度分布 } \\
{[\mathrm{mm}]}\end{array}$ & $\begin{array}{c}\text { 表乾比重 } \\
{[-]}\end{array}$ & $\begin{array}{c}\text { 吸水率 } \\
{[\%]}\end{array}$ & 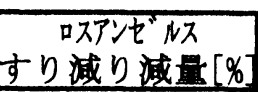 & $\begin{array}{c}\text { 旧モース硬度 } \\
{[-]}\end{array}$ \\
\hline セラサント & $8 \sim 13$ & 2.3 & 0.5 & 15.1 & 7.5 \\
\hline
\end{tabular}

表 2 ジオシンセティックスの種類と物性

\begin{tabular}{|c|c|c|c|c|c|}
\hline 項 目 & $\begin{array}{ll}\text { 種 類 } \\
\end{array}$ & $\begin{array}{l}\text { 目 付 } \\
{\left[\mathrm{g} / \mathrm{m}^{2}\right]}\end{array}$ & $\begin{array}{c}\text { 厚 さ } \\
{[\mathrm{mm}]{ }^{*} 1}\end{array}$ & $\begin{array}{c}\text { 引張強さ（機械／幅） } \\
{[\mathrm{kN} / \mathrm{m}]{ }^{*} 2} \\
\end{array}$ & $\begin{array}{l}\text { 伸び率 } \\
{[\%] * 2} \\
\end{array}$ \\
\hline \multirow{3}{*}{ 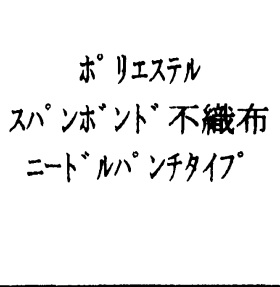 } & $\begin{array}{ll}\text { S B } & 1\end{array}$ & 110 & 1.2 & $\begin{array}{c}6.9 / 3.5 \\
(35 / 18[\mathrm{kgf} / 5 \mathrm{~cm}])\end{array}$ & $66 / 94$ \\
\hline & $\begin{array}{ll}\text { S B } 2 \\
\end{array}$ & 210 & 1.9 & $\begin{array}{c}18.6 / 9.8 \\
(95 / 50[\mathrm{kgf} / 5 \mathrm{~cm}]) \\
\end{array}$ & $57 / 69$ \\
\hline & $\begin{array}{lll}\text { S B } & 3\end{array}$ & 310 & 3.0 & $\begin{array}{c}30.6 / 15.5 \\
(156 / 79[\mathrm{kgf} / 5 \mathrm{~cm}]) \\
\end{array}$ & $66 / 77$ \\
\hline $\begin{array}{l}\text { 术リエステN } \\
\text { 織布 }\end{array}$ & $\mathrm{PE}$ & 220 & 0.4 & $\begin{array}{c}74.5 / 74.5 \\
(380 / 380[\mathrm{kgf} / 5 \mathrm{~cm}]) \\
\end{array}$ & $26 / 26$ \\
\hline
\end{tabular}

* 1 ; 圧縮荷重 $20 \mathrm{gf} / \mathrm{cm}^{2}$

*2; 引張速度 $20 \mathrm{~cm} / \mathrm{min}$, 試験片幅 $5 \mathrm{~cm}$ (織布 $3 \mathrm{~cm}$ ), つかみ間隔 $10 \mathrm{~cm}$ 


\section{4. 検剖手順}

評価法確立を目指し、平成 9 年度 ${ }^{11}$ および 10 年度 ${ }^{2)}$ 調査研究における検討手順を図 3 に示す。

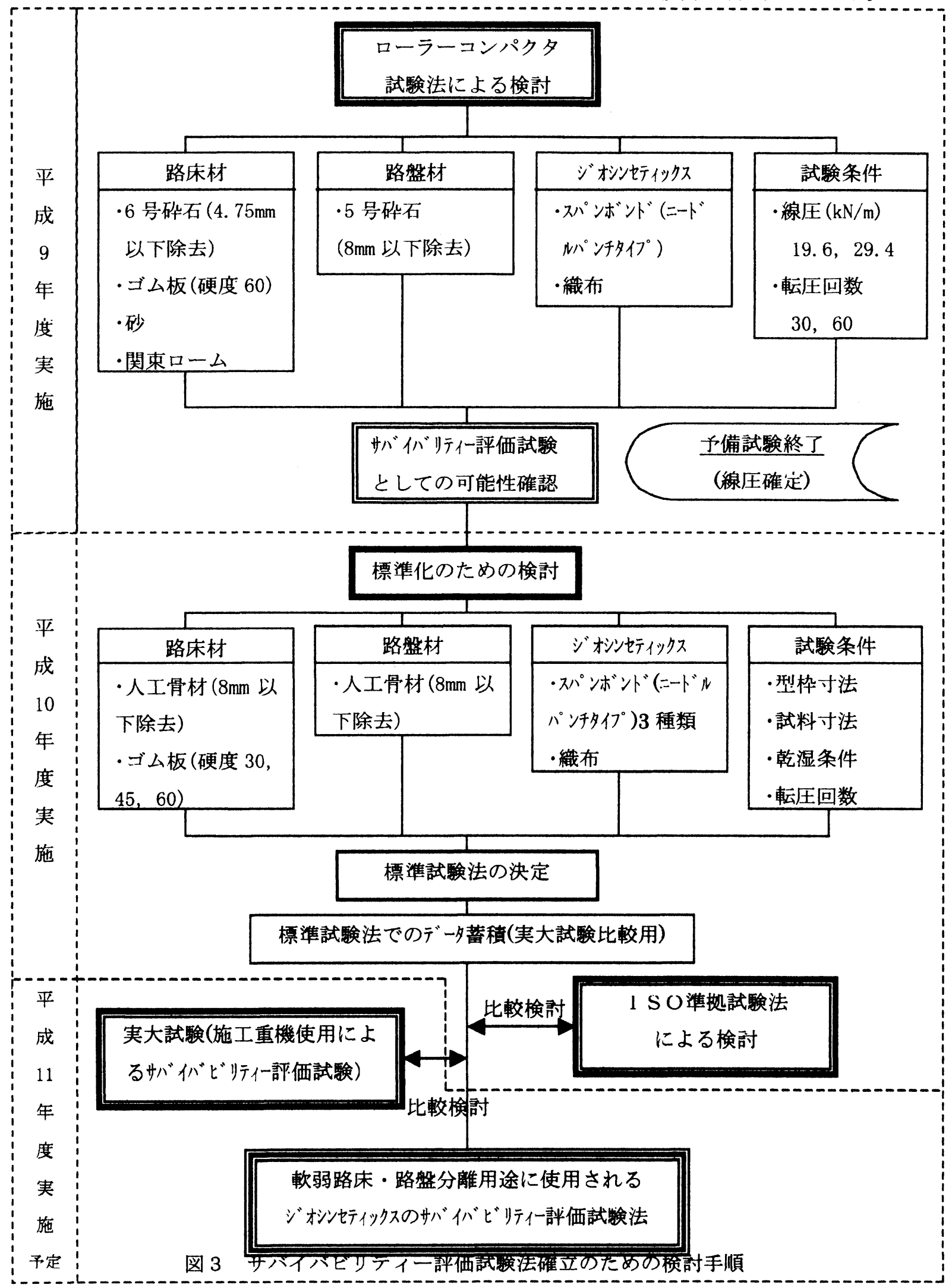


【試験条件】線圧 : $30 \mathrm{kgf} / \mathrm{cm}$ ，路床材：セラサント 6 号砕石

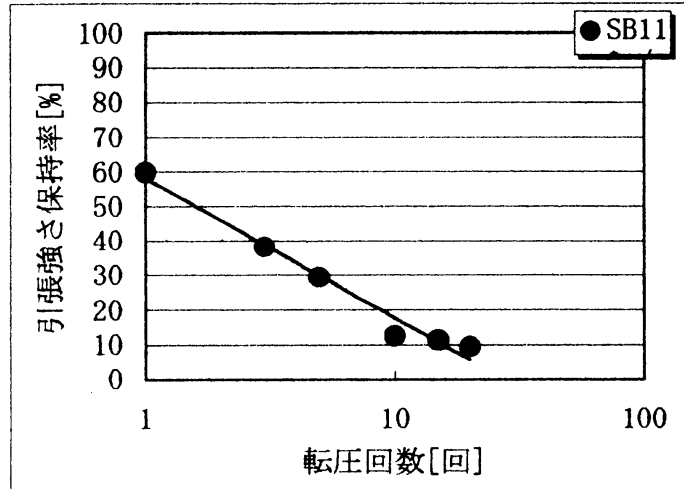

図4 SB1引張強さ保持率
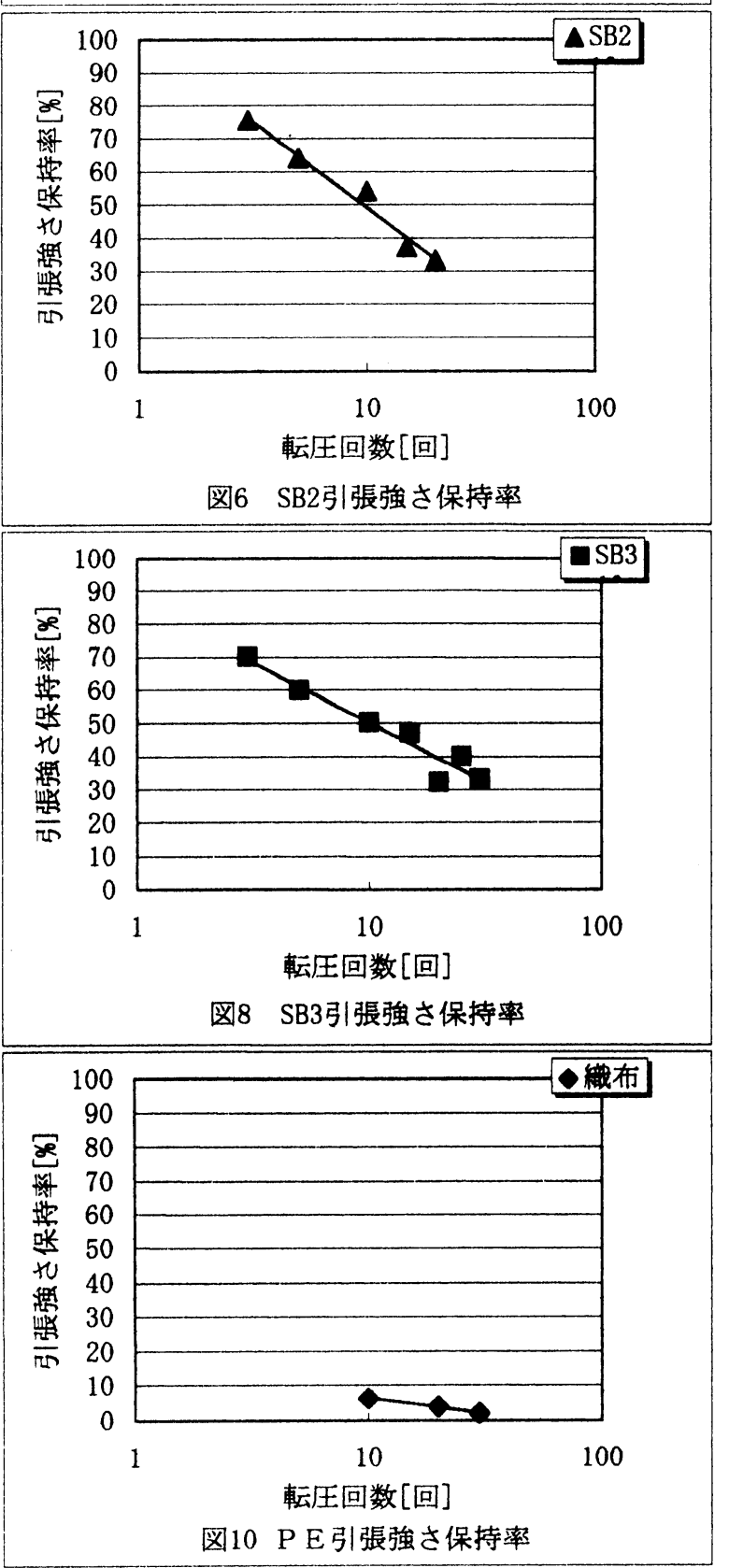

【試路条件】線圧：30kgf/cm，路床材：ゴム（硬度 $30 ）$

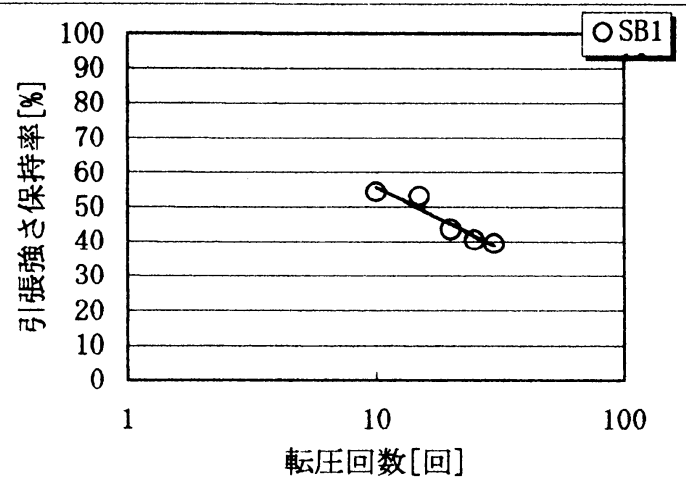

図5 SB1引張強さ保持率

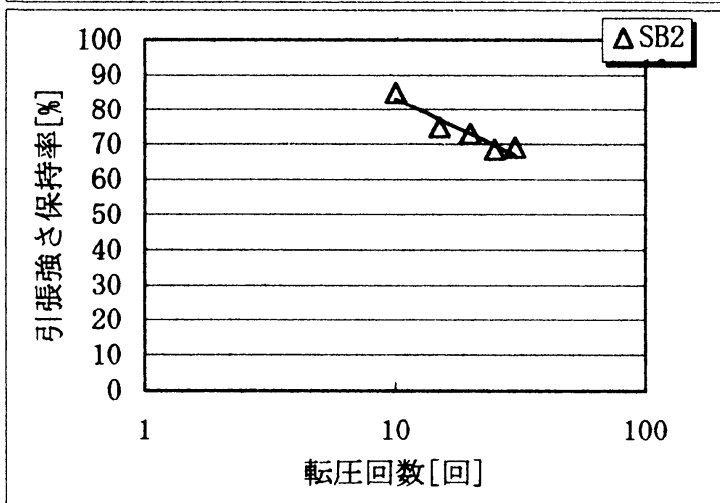

図7 SB2引張強さ保持率
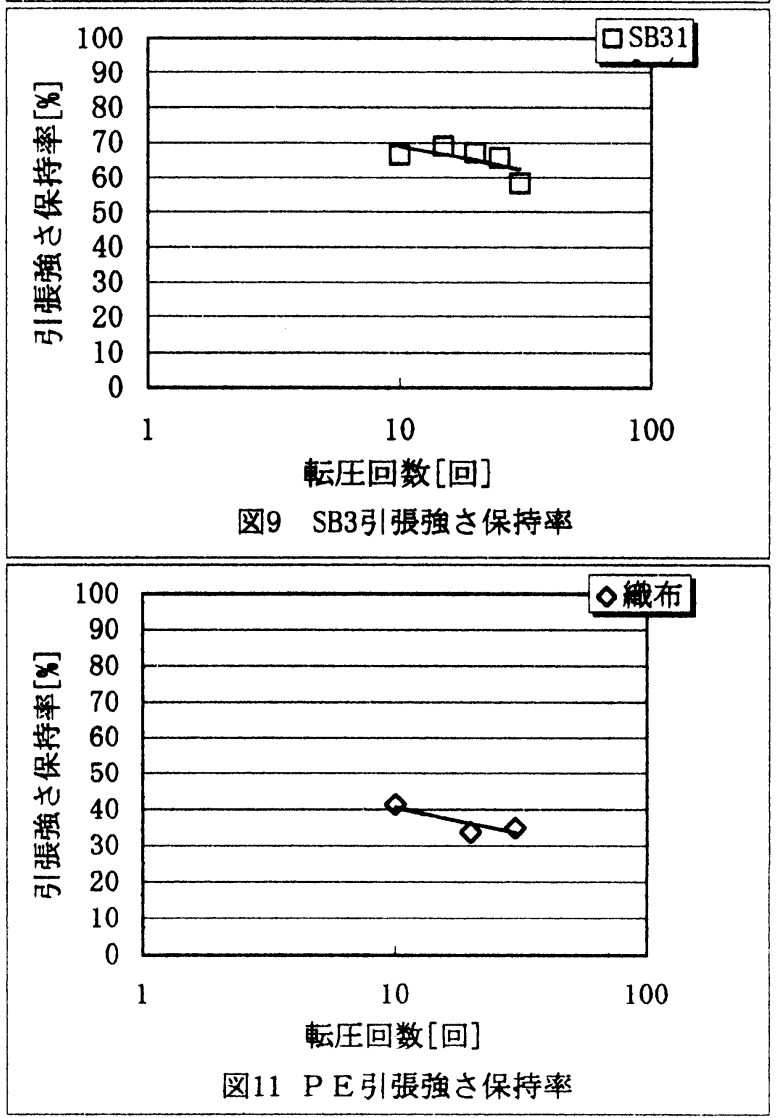
5. 結果および考察

(1) ローラーコンパクタ試験法による検討

平成 10 年度調查研究である標淮試験法でのローラーコンパクタ試験法によろサバイバビリティー評 価試験結果について述べる。

1 ) 図 4〜 11 は線圧を $29.4 \mathrm{kN} / \mathrm{m}(30 \mathrm{kgf} / \mathrm{cm})$ に設定し、路床材に硬質人工 6 号砕石（セラサンド 6 号砕石）と硬度 30 ウレタンゴムを使用した場合の転圧回数に対する各ジオシンセティックスの引張強 さ保持率の関係を示す。これらの図から、以下のことが判った。

(i)転圧回数の增加と共に引張強さ保持率は低下した。

(2)路床材にセラサンド 6 号砕石を使用した場合の方が保持率低下は大きかった。

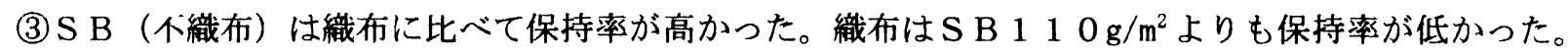
(4)外観目視観察では、織布は同程度目付のS B $210 \mathrm{~g} / \mathrm{m}^{2}$ と比較すると買通孔数が多く、また貫通孔径 も大きい傾向にあった。ただし、S B $110 \mathrm{~g} / \mathrm{m}^{2}$ は明らかに織布よりも貫通孔数が多く、また貫通孔径も 人きかったが、保持率は織布よりも多少高い傾向にあった。これは、不織布のランダムな䋐維配列に起因 しているものと考えられる。すなわち、引張試験時に損傷部に応力が集中せず、他の瀻維ネットワークを 伀わって応力が分散していくためと考えられる。

2)図 12 はジオシンセティックスに各 S B ( $\left.1110 、 210 、 310 \mathrm{~g} / \mathrm{m}^{2}\right)$ 、路床材にセラサンド 6 号 砕石と硬度 30 ゴムを使用した場合の転圧回数に対する中心部沈下量と水下移動量の関係を示す。この図 から、路床材にセラサンド 6 号砕石を使用した時の方が中心部沈下量は大きく、水平移動量は小さい傾向 にあった。よって、S Bに働く貫入力や圧縮力は硬度 30 ゴムを使用した場合より大きいと考えられる。

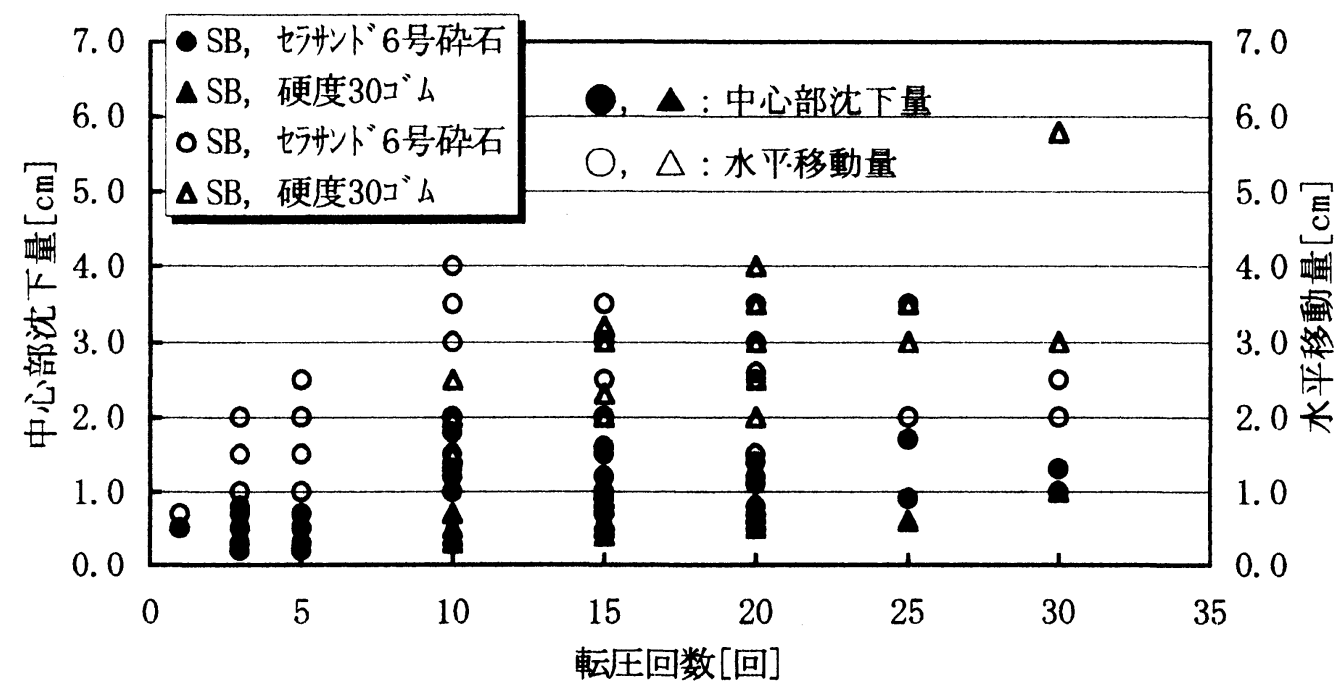

図 12 中心部沈下量と材水平移動量の関係（S B） 
3 ) 図 13 はジオシンセティックスに織布、路床材にセラサンド 6 号砕石と硬度 30 ゴムを使用した場合 の転圧回数に対する中心部沈下量と水平移動量の関係を示す。この図から、織布の場合も同様、路床材に セラサンド 6 号砕石を使用した時の方が中心部沈下量は大きく、水平移動量は小さい傾向にあった。

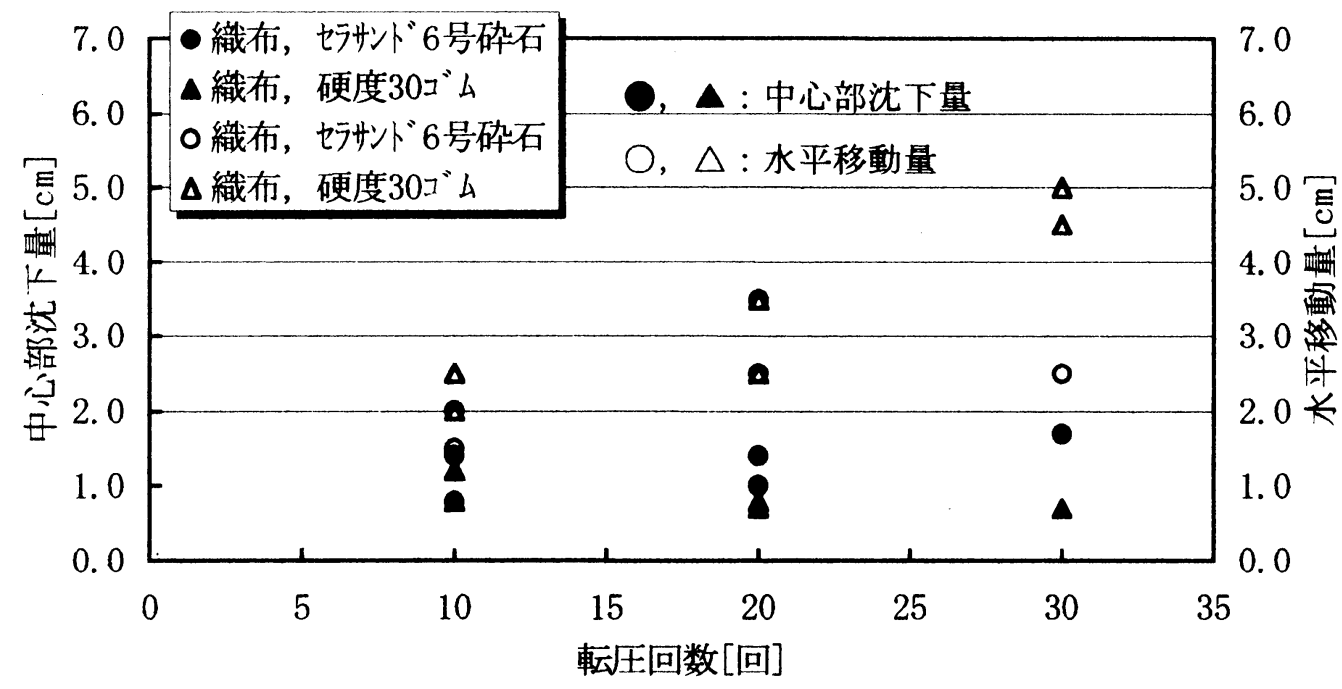

図 13 中心部沈下量と材水平移動量の関係（織布）

4)図 14 はジオシンセティックスに各S B （1 $110 、 210 、 310 \mathrm{~g} / \mathrm{m}^{2} ）$ と織布、路床材にセラサン ド 6 号砕石と硬度 30 ゴムを使用した場合の中心部沈下量と引張強さ保持率の関係を示す。この図から、 中心部沈下量の増加と共に引張強さ保持率も低下する傾向にあった。また、路床材にセラサンド 6 号砕石 を使用した時の方が引張強さ保持率は低く、中心部沈下量も大きい傾向にあった。このことから、中心部 沈下量の増加と共にジオシンセティックスに働く貫入力や厈縮力は増大するものと推定される。

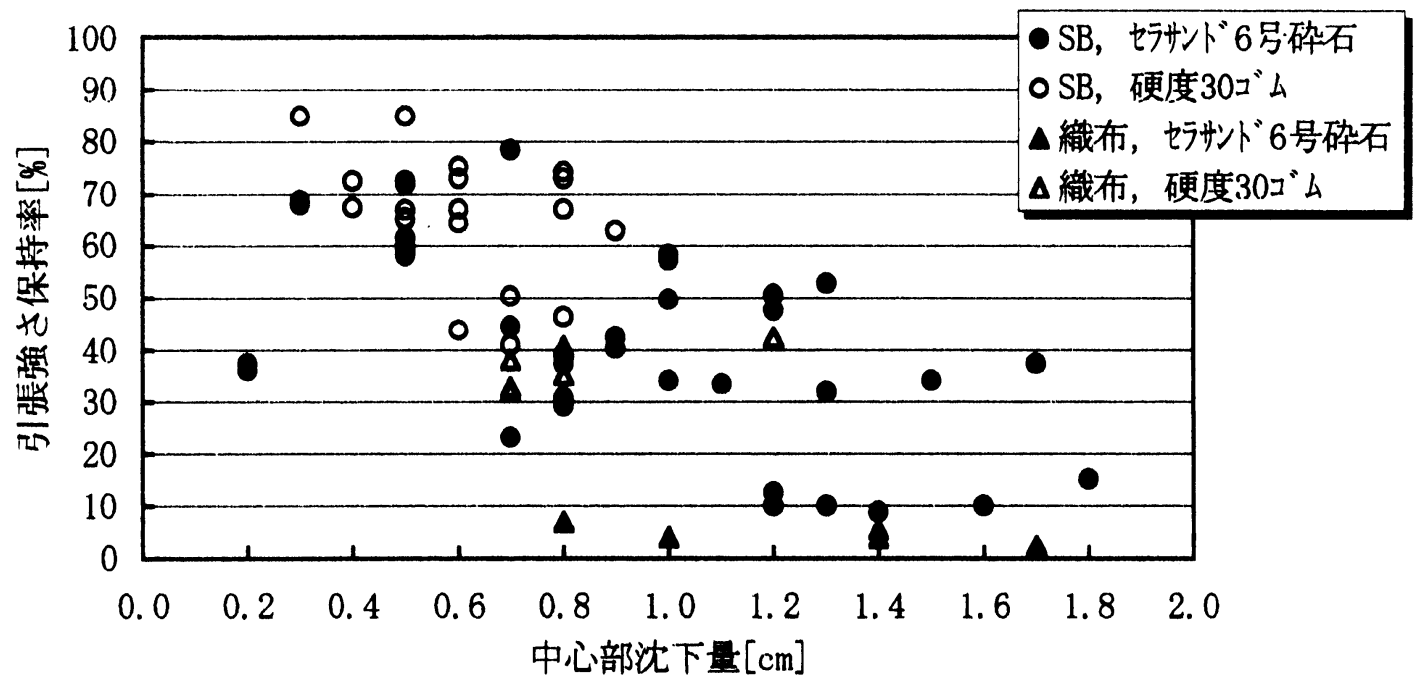

図 14 中心部沈下量と引張強さ保持率の関係 
以上 1 ) 〜 4)より、

・不織布は織布よりもサバイバビリティーが高い。

- 中心部沈下量の増加と共にジオシンセティクスに働く貫入力や圧縮力が増大し、損甥は大きくなる。 と推定される。

（2）I S O淮拠試験法による検討およびローラーコンパクタ試験法との比較検討

上記ローラーコンパクタ試験法と比較検討を行うため、同じ標淮材料を使用し、I S Oに準拠した試験 方法よってサバイバビリティー評価試験を実施した。その結果を以下に述べる。

1) 表 3 および汹 15 に I S O準拠試験法による試験結果を示す。表 3 から、引誩強さ保持率は路床材が セラサンド 6 号砕石<硬度 60 ゴム<硬度 45 ゴム<硬度 30 ゴムの順に低トする傾向にあった。このこ とから、路床材が軟らかく（硬度が低く）なるにつれて引張強さ保持率は低下する傾向にあると考えられ る。これはローラーコンパクタ試験法による結果と全く逆の傾向であった。

2 ) 図 15 から、沈下量の增加と共に引張強さ保持率は低下する傾向あった。しかし、路床材に硬度 30 ゴムを使用した時に最も沈下量が大きくなり、これはローラーコンンパクタ試験法による絬果と全く逆の 傾向を示した。

表 3 I S O 準拠試験法による沈下量および引張強さ保持率

\begin{tabular}{|c|c|c|c|c|c|}
\hline No. & $\begin{array}{c}\text { 路盤材 } \\
\text { 路盤材厚: } 30 \mathrm{~mm}\end{array}$ & ジオシンセテイックス & $\begin{array}{c}\text { 路床材 } \\
\text { 路床材厚: } 75 \mathrm{~mm}\end{array}$ & $\begin{array}{c}\text { 沈下量 } \\
{[\mathrm{cm}]}\end{array}$ & $\begin{array}{c}\text { 引張強さ } \\
\text { 保持率 [\%] }\end{array}$ \\
\hline 1 & \multirow{3}{*}{ セラサンド 6岇砕石 } & $\mathrm{SB} 110 \mathrm{~g} / \mathrm{m}^{2}$ & \multirow{3}{*}{ セラサンド 6岇砕石 } & 0.94 & 46 \\
\hline 2 & & $\mathrm{SB} 210 \mathrm{~g} / \mathrm{m}^{2}$ & & 0.88 & 59 \\
\hline 3 & & $\mathrm{SB} 110 \mathrm{~g} / \mathrm{m}^{2}$ & & 0.94 & 73 \\
\hline 4 & \multirow{3}{*}{ セラサンド 6号砕石 } & $\mathrm{SB} 110 \mathrm{~g} / \mathrm{m}^{2}$ & \multirow{3}{*}{ 硬度60コ“ム } & 1.81 & 0 \\
\hline 5 & & $\mathrm{SB} 210 \mathrm{~g} / \mathrm{m}^{2}$ & & 1.95 & 16 \\
\hline 6 & & $\mathrm{SB} 310 \mathrm{~g} / \mathrm{m}^{2}$ & & 2.10 & 44 \\
\hline 7 & \multirow{3}{*}{ セラサンド 6号砕石 } & $\mathrm{SB} 110 \mathrm{~g} / \mathrm{m}^{2}$ & \multirow{3}{*}{ 硬度 45 ב"ム } & 1.85 & 0 \\
\hline 8 & & $\mathrm{SB} 210 \mathrm{~g} / \mathrm{m}^{2}$ & & 2.03 & 6 \\
\hline 9 & & $\mathrm{SB} 310 \mathrm{~g} / \mathrm{m}^{2}$ & & 2.29 & 39 \\
\hline 10 & \multirow{3}{*}{ 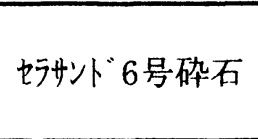 } & $\mathrm{SB} 110 \mathrm{~g} / \mathrm{m}^{2}$ & \multirow{3}{*}{ 硬度 30ゴム } & 2.09 & 0 \\
\hline 11 & & $\mathrm{SB} 210 \mathrm{~g} / \mathrm{m}^{2}$ & & 2.26 & 0 \\
\hline 12 & & $\mathrm{SB} 310 \mathrm{~g} / \mathrm{m}^{2}$ & & 2.37 & 35 \\
\hline
\end{tabular}




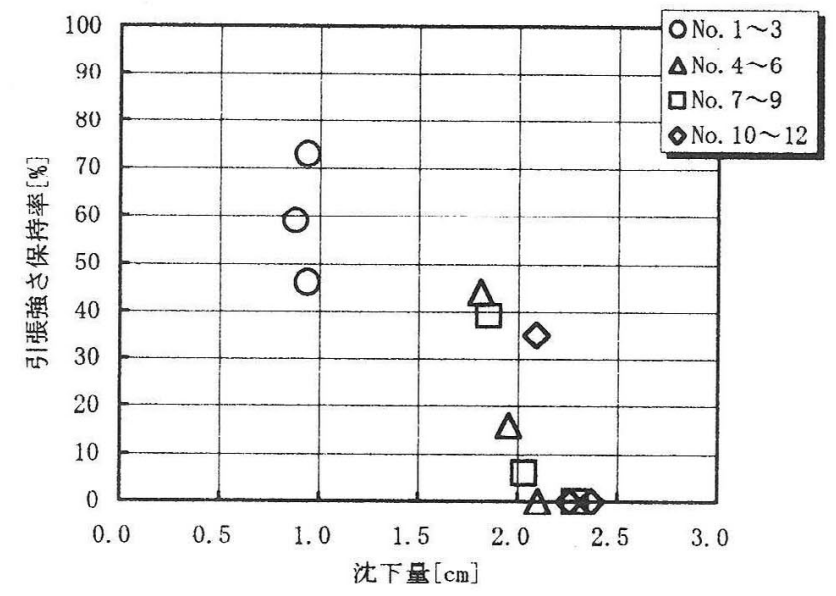

図 15 I S O 潐拠試験法における沈下量と引張強さ保持率の関係

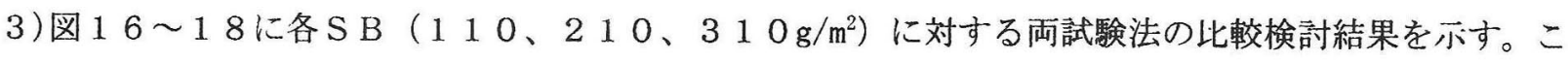
れらの図から、ローラーコンパクタ試験法とI S O 準拠試験法でジオシンセティックスの受ける損倁が全 く逆になっていることが判る。

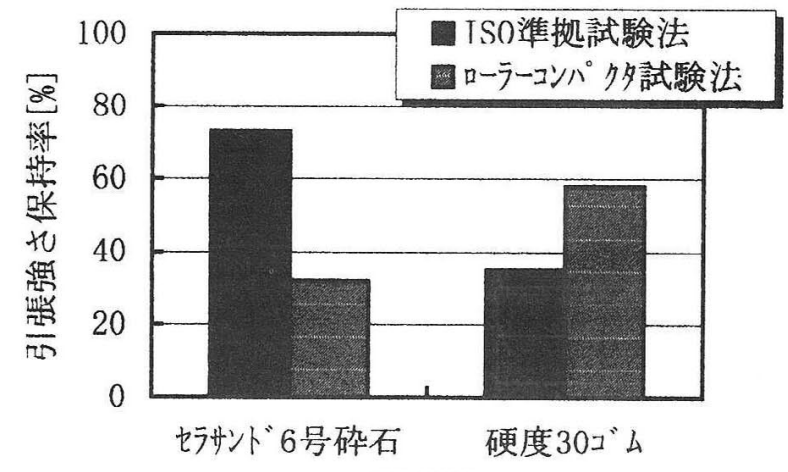

路床材

図16 両試験法の比較 $\left(\mathrm{SB} 310 \mathrm{~g} / \mathrm{m}^{2}\right)$

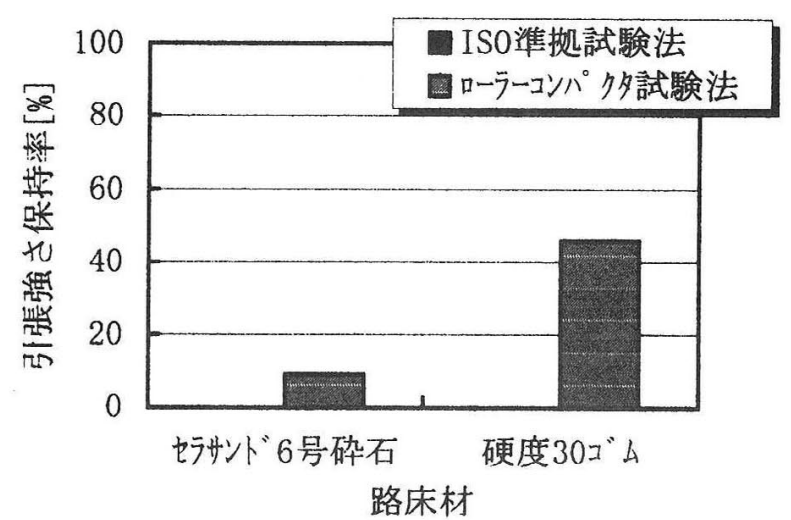

図 18 両試験法の比較 $\left(\mathrm{SB} 110 \mathrm{~g} / \mathrm{m}^{2}\right)$

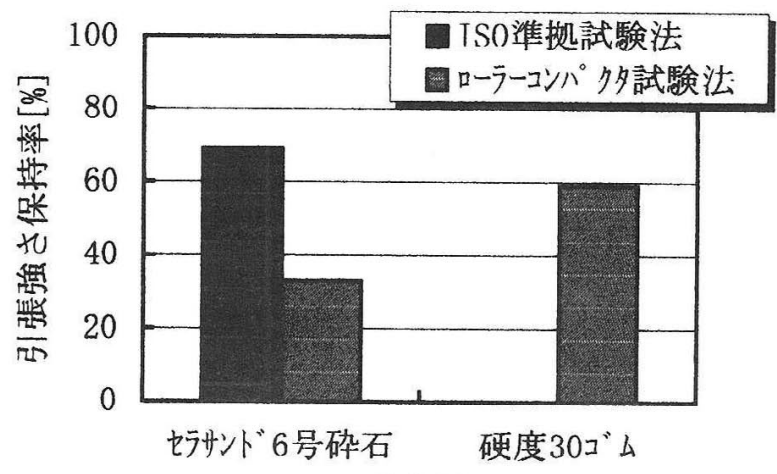

路床材

図17 両試験法の比較 $\left(\mathrm{SB} 210 \mathrm{~g} / \mathrm{m}^{2}\right)$

※ ローラーコンパクタ試験法は、 転圧回数 20 回の場合の結果を 用いた。 
以上 1 ) 3) より、I S O準拠試験法とローラーコンパクタ試験法で引張強さ保持率が全く逆の傾向を 示すことが判った。この原因の一つとしては、転圧（あるいは載荷）時の型枠内での砕石の移動しやすさ が異なるためと推定される。ローラーコンパクタ試験法では全面転圧されるため、型枠内全体の砕石が最 密充填しやすいのに対し、I S O 準拠試験法では部分載荷のため、型枠内全体の砕不が最密充填せず、載 荷プレート直下にのみ応力が集中する。よって、砕石のより移動しやすい（沈下量が大きくなる）硬度の 低い路床材使用時に損傷が大きくなると考えられる。すなわち、両試験法においてジオシンセティックス に働く破壊力の作用の仕方が異なるものと考えられる。

6.まとめ

ローラーコンパクタ試験法と I S O 準拠試験法でジオシンセティックスの破壊に至るメカニズムが異 なることが判った。どちらの試験法が妥当であるかは現仕のところ不明であるが、実際の施工現場と整合 性のある試験方法の開発が目慓であることから、実大試験や過去の事例調査、当研究会で実施した試験施 工の開削調査などとの比較検討を行い、本用途におけるサバイバビリティー評価試験法を確立していく。

\section{【参考文献】}

1 ) 飯島尚、池田拓哉、他: 道路・舖装分野におけるジオテキスタイルの耐久性評価手法に係る調查研究、 平成 9 年度通商産業省工業技術院委託成果報告書、p p . $35 \sim 51$ （1998）

2 ) 飯島尚、池田拓哉、他 : 道路・舗装分野におけるジオテキスタイルの耐久性評価千法に係る調查研究、 平成 10 年度通商産業省工業技術院委託成果報告書、p p . 1 7 7 (1999) 